\title{
Analisis Akurasi Kombinasi Proses Text Mining Dan Certainty Factor Dalam Diagnosis Kerusakan Printer
}

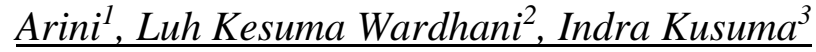 \\ Teknik Informatika, Fakultas Sains dan Teknologi, Universitas Islam Negeri Syarif Hidayatullah Jakarta ${ }^{1,2,3}$ \\ Jl. Ir. J. Juanda No. 95, Ciputat, Jakarta, Indonesia \\ arini@uinjkt.ac.id ${ }^{1}$,luhkesuma@uinjkt.ac.id ${ }^{2}$,indra.kusuma14@mhs.uinjkt.ac.id ${ }^{3}$
}

\begin{abstract}
Printers have many problems or damages, at this research use New Epson Printer problem. The problems can be solved by expert system that can replace the role of humans in a computer system and can help solve an existing problem. Expert systems have many methods one of which is certainty factor, certainty factor is very suitable to be used to assess data whose answer is uncertain as possible, most likely, almost certain, etc., while the nazief \& adriani algorithm to process a sentence search. Both of this methods combined at this research which found the accuracy of 58,33\%. For the next development can be used string matching algorithm.
\end{abstract}

Keywords : Expert system, printer damage, Nazief \& Adriani, Certainty factor

\begin{abstract}
Abstrak
Printer memiliki banyak sekali masalah atau kerusakan, dalam penelitian ini adalah kerusakan printer Epson Terbaru. Masalah ini dapat dipecahkan dengan menggunakan sistem pakar yang mampu menggantikan peran manusia dalam memecahkan masalah. Sistem pakar yang digunakan dalam penelitian ini adalah certainty factor dengan alasan bahwa certainty factor sangat cocok digunakan untuk menilai data yang jawabannya belum pasti seperti mungkin, kemungkinan besar, hampir pasti, dan lainlain, sedangkan algoritma nazief \& adriani dalam penelitian ini dipilih untuk memproses pencarian kalimat. Dengan penggabungan keduanya menghasilkan tingkat akurasi yaitu 58,33\% dalam mendiagnosis kerusakan printer. Pengembangan kedepan sistem ini dapat menggunakan algoritma string matching.
\end{abstract}

Kata kunci : Sistem Pakar, kerusakan printer, Nazief \& Adriani, Certainty factor

\section{Pendahuluan}

Mesin cetak dibuat pertama kali oleh Johannes Gutenberg pada tahun 1440 di kota Mainz, Jerman [1] Sampai saat ini semakin canggihnya teknologi dan banyak sekali orang pintar yang mempelajari ilmu maka semakin canggih pula mesin yang dibuatnya.

Usaha mikro kecil dan menengah yang biasa disebut UMKM merupakan pelaku bisnis yang bergerak pada berbagai bidang usaha, salah satu contoh UMKM adalah usaha warnet yang saat ini dibutuhkan banyak kalangan karena kebutuhan pasar yang meningkat karena semua informasi semakin cepat dan canggih, para pemilik usaha warnet-pun ingin mencoba hal baru dengan menambahkan usaha percetakan digital printing di warnet-nya. Dari hasil wawancara yang telah dilakukan oleh penulis dengan bapak Amir Sefulloh selaku pemilik usaha warnet, ada beberapa yang membuat pesimis didalam benak pemilik warnet karena besarnya biaya yang harus dikeluarkan untuk perawatan mesin cetak (Printer). Printer yang dipakai oleh pemilik percetakan-percetakan pada umumnya sebagian besar memakai printer merk EPSON. Majalah kompas mengatakan bahwa Lembaga riset IDC Asia/Pacific merilis hasil riset pasar printer (hardcopy peripherals/HCP) kuartal-IV 2017 di Indonesia. Menurut. IDC, pasar printer Indonesia mengalami kenaikan 0,6 persen pertahunnya. Pasar printer inkjet tumbuh sebesar 0,3 persen dibandingkan akhir 2016, dengan pengiriman total 1,8 juta unit. Pertumbuhan pada HCP terutama didorong oleh printer tinta tangki yang mencatat pertumbuhan 17,5 persen. Sementara pasar printer laser termasuk mesin fotokopi, pada akhir 2017 mencatat pengiriman sekitar 180.000 unit dengan 
pertumbuhan 8,1 dibandingkan tahun sebelumnya. Seiring dengan berkembangnya teknologi, khususnya di bidang sistem informasi, permasalahan kerusakan printer juga menjadi masalah yang cukup serius, hal ini dapat dimaklumi mengingat banyaknya user yang kurang memiliki pengetahuan tentang printer, khususnya dalam menangani printer yang mengalami kerusakan yang terjadi belum tentu rumit dan tidak dapat diperbaiki sendiri [2]. Untuk itulah perlu dibuat sistem yang dapat membantu memecahkan permasalahan kerusakan printer.

Banyak penggunaan sistem pakar yang mengimplementasikan kecerdasan seorang pakar dalam bidangnya. Pada penelitian yang dilakukan oleh [2], mereka membuat sistem pakar diagnosis kerusakan printer hanya dengan 1 metode yaitu forward chaining dan 1 jenis tipe printer. Dan Pada penelitian [3], mereka membuat sistem pakar kerusakan printer dengan hanya 1 metode yaitu forward chaining. Sedangkan pada [4], mereka melakukan penelitian sistem pakar diagnosis kerusakan printer dengan metode certainty factor dengan 2 jenis printer yang dipakai untuk penelitian, user memilih gejala yang sesuai dengan menceklis kolom yang ada pada menu gejala. Sedangkan menurut data dari EPSON AUTHORIZED SERVICE CENTER, 65\% user tidak dapat memahami perangkat-perangkat yang ada pada printer sehingga user tidak bisa menggunakan sistem pakar tersebut. Hal ini yang membuat penulis untuk melakukan atau mengkombinasikan penggunaan ceklis kolom dengan menu pencarian. Pada [5] dan [6], metode Certainty Factor digunakan untuk penyakit, dan [7] menggabungkan metode Certainty Factor dengan forward chaining untuk diagnosis penyakit. Sedangkan pada [8], metode yang digunakan adalah dempster shafer. Pada penelitian [9], dilakukan penelitian tentang implementasi algortima boyer moore pada aplikasi kamus istilah kebidanan berbasis web, dapat disimpulkan bahwa algoritma Boyer Moore hanya bisa mencari kata yang sesuai dengan database karena didalam proses pre-procesing tidak ada tahapan seperti : cashfolding, filtering, tokenizing dan stemming. Penelitian [10] diketahui bahwa algoritma Nazief dan Adriani terbaik dalam proses stemming yaitu karena memiliki hasil evaluasi yang lebih tinggi.

Pada penelitian ini dibuat analisis dalam pemecahan masalah diagnosis kerusakan printer dengan algoritma Nazief dan Adriani mengkombinasikan dengan algoritma Certainty Factor dengan kriteria menggunakan 35 gejala dan 6 jenis kerusakan. Printer yang digunakan adalah printer EPSON seri terbaru. Pembuatan aplikasi menggunakan bahasa pemrograman PHP dengan framework Laravel, Algoritma stemming yang digunakan pada mesin pencarian adalah algoritma Nazief \& Adriani, dapat dilihat pada Gambar 1. Kamus yang dipakai adalah kamus KBBI. Metode certainty factor untuk menentukan nilai kepercayaan dari kerusakan yang telah ditentukan melalui proses pencarian kata atau pemilihan gejala dapat dilihat pada Gambar 2.

Faktor kepastian (certainty factor) merupakan ukuran kepastian terhadap suatu fakta atau aturan. Faktor kepastian (certainty factor) menunjukan ukuran kepastian terhadap fakta dan aturan [6].

\section{Metodologi}

Dalam pengembangan sistem ini, digunakan metodologi pengembangan sistem dengan metode RAD dengan alasan bahwa RAD menghasilkan suatu sistem dengan cepat karena sistem yang dikembangkan dapat memenuhi keinginan dari para pemakai sehingga dapat mengurangi waktu untuk pengembangan ulang setelah tahap implementasi

Berikut 3 fase yang digunakan dalam penelitian dengan mengacu dari metode RAD [11], [12] yaitu :

1) Fase Perencanaan Syarat-Syarat.

2) Fase workshop Desain

3) Fase Implementasi. 


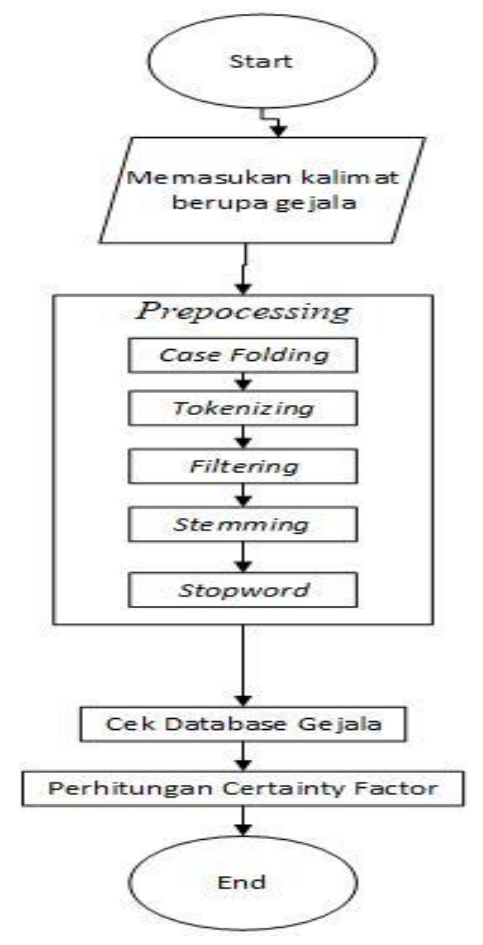

Gambar 1. Proses Pencarian

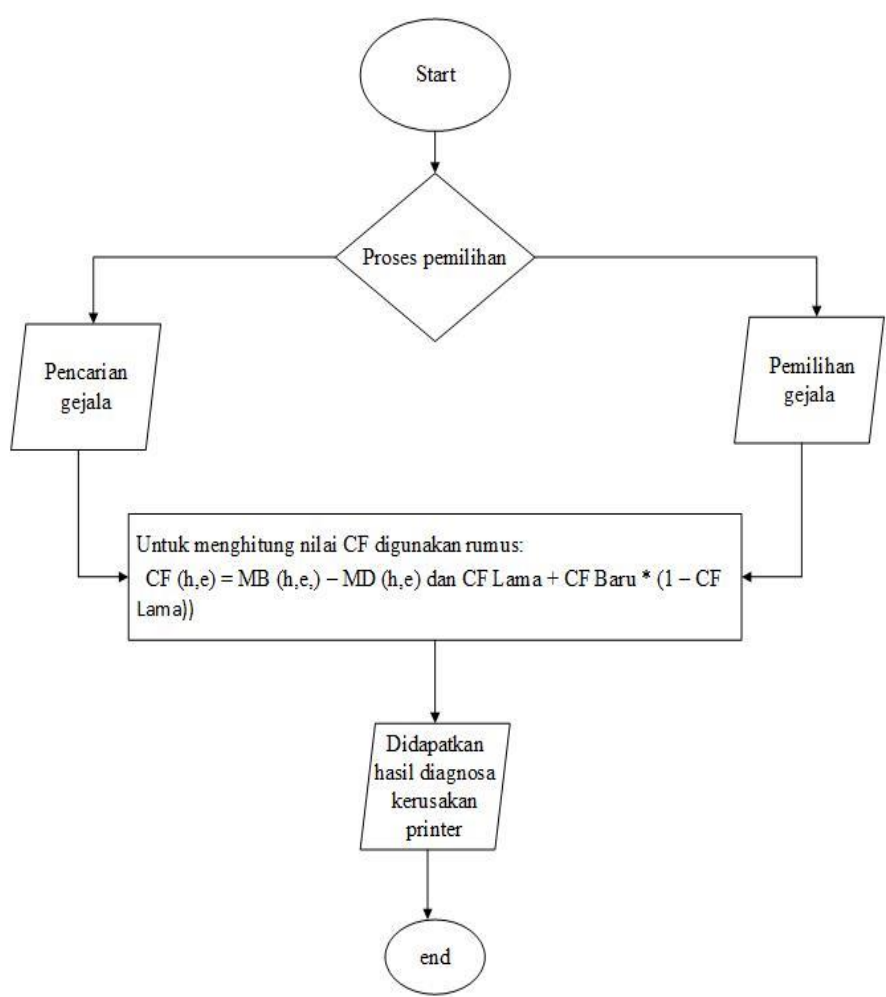

Gambar 2. Flowchart Proses Algoritma Certainty Factor 


\subsection{Fase Perencanaan Syarat-syarat}

Dalam fase ini, pengguna dan penganalisis bertemu untuk mengidentifikasikan tujuan-tujuan aplikasi atau sistem serta untuk mengindentifikasikan syarat-syarat informasi yang ditimbulkan dari tujuan-tujuan tersebut. Orientasi dalam fase ini adalah menyelesaikan masalah-masalah yang ada di perusahaan. Meskipun teknologi informasi dan sistem bisa mengarahkan sebagian dari sistem yang diajukan, fokusnya akan selalu tetap pada upaya pencapaian tujuan-tujuan perusahaan. Menggunakan sistem wawancara dengan salah satu teknisi kantor perusahaan EPSON AUTORIZED SERVICE CENTER, dan yang dikeluhkan adalah printer yang mempunyai banyak kendala.

\subsection{Fase Workshop Desain}

Fase ini adalah fase untuk merancang dan memperbaiki yang bisa digambarkan sebagai workshop. Penganalisis dan pemrograman dapat bekerja membangun dan menunjukkan representasi visual desain dan pola kerja kepada pengguna (masyarakat). Workshop desain ini dapat dilakukan selama beberapa hari tergantung dari ukuran aplikasi yang akan dikembangkan. Selama workshop desain RAD, pengguna merespon prototipe yang ada dan penganalisis memperbaiki modul-modul yang dirancang berdasarkan respon pengguna. Dengan menggunakan Unified Modeling Language (UML) untuk pemodelan system, PHP untuk membuat sistem pakar berbasis website, MySQL untuk penyimpanan datanya dan untuk menghias dan mengatur gaya tampilan/layout halaman web menggunakan Cascading Style Sheet (CSS) serta JavaScript (JS) untuk menyisipkan dalam HTML Pencarian Kata (String Matching) berupa keluhan dari kerusakan printer dengan menggunakan algoritma Nazief \& Adriani dan hasilnya akan di proses oleh Algoritma Certainty factor sehingga mendapatkan hasil dari diagnosa kerusakan printer. Proses pemilihan gejala kerusakan printer (Cek Box) dan diproses oleh algoritma Certainty Factor sehingga mendapatkan hasil dari diagnosa kerusakan printer.

\subsection{Fase Implementasi}

Pada fase implementasi ini, penganalisis bekerja dengan para pengguna secara intens selama workshop dan merancang aspek-aspek bisnis dan nonteknis perusahaan. mengimplementasikan bahasa pemprograman yakni dengan menggunakan bahasa PHP dan basis data atau database berupa MySQL. Sebagai akhir dari tahap ini penulis juga meminta tanggapan user terhadap aplikasi yang sudah di uji coba, agar dapat di evaluasi untuk pengembangan sistem selanjutnya

\section{Hasil dan Pembahasan}

\subsection{Tahap Perencanan}

Tujuan dari perencanaan syarat tentang diagnosis kerusakan printer sebagai referensi informasi tentang apa saja yang dibutuhkan dalam mengetahui kerusakan printer. Informasi ini penting untuk diperoleh agar aplikasi dapat menyajikan kebutuhan user untuk mengetahui kerusakan printer. Informasi diperoleh melalui wawancara para pengguna printer. Perbedaan tabel 1 adalah kerusakan pada inti printer sedangkan tabel 2 adalah gejala-gejala pada kerusakan printer.

Tabel 1. Kerusakan Inti Printer

\begin{tabular}{ll}
\hline No & Diagnosis Kerusakan Printer \\
\hline 1 & General Eror \\
2 & Scanner Eror \\
3 & Head Tersumbat/Tinta Tidak Keluar \\
4 & Paper Jam \\
5 & Mati Total \\
6 & Mainboard rusak \\
\hline
\end{tabular}


Tabel 2. Gejala Kerusakan Printer

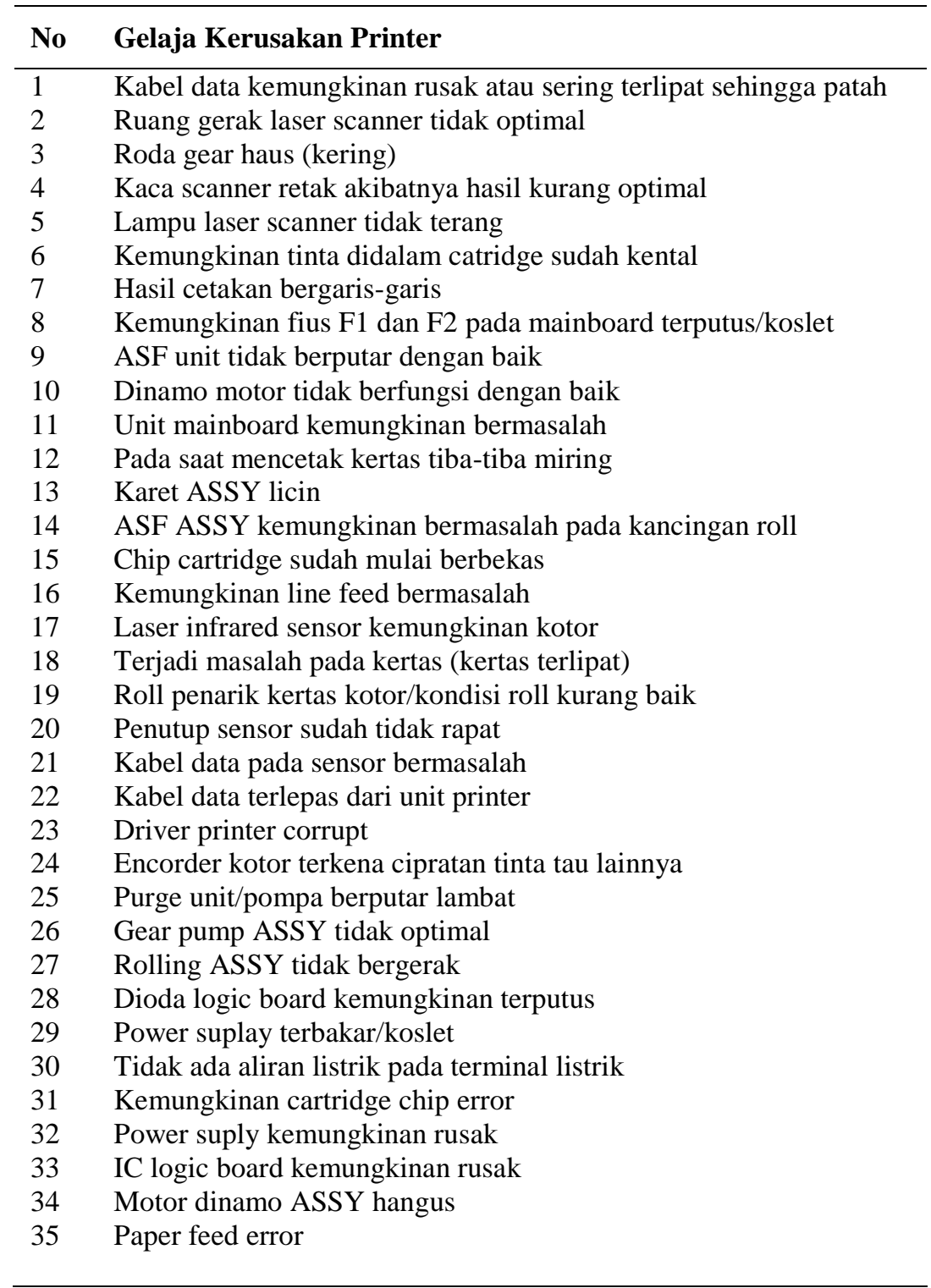

Kerusakan inti dan gejala memiliki relasi masing masing yang dapat dilihat pada tabel 3 .

Tabel 3. Relasi Kerusakan Printer

\begin{tabular}{cll}
\hline No & No. Penyakit & No. Gejala \\
\hline 1 & 01 & $3,14,16,17,18,19,20,21,23,26,29$ \\
2 & 02 & $1,2,3,4,5$ \\
3 & 03 & $6,7,8$ \\
4 & 04 & $2,9,10,12,13,14,21,22,27$ \\
5 & 05 & $12,24,25,28,30,31,32$ \\
6 & 06 & $11,15,33,34,35$ \\
& & \\
\hline
\end{tabular}




\subsection{Tahap Workshop Desain}

Pada tahap ini dilakukan perhitungan manual dan dimasukan kedalam system. Analisis data masukan, contoh yang dialami dari kerusakan printer "Laser Scanner yg ada di PRINTER tidak optimal, roda gear mengering dan fius koslet". Melakukan proses text mining, ini dilakukan sebelum metode klasifikasi. Tujuan dari tahap ini adalah menghilangkan noise, menyeragamkan bentuk kata dan mengurangi volume kosakata. Tahap ini meliputi case folding, tokenizing, penghapusan stopword dan stemming. Berikut penerapan pada tahap praproses dokumen pada sistem klasifikasi :

1. CashFolding

Pada tahap ini dilakukan pengubah huruf dalam dokumen menjadi huruf kecil. Hanya huruf 'a' sampai dengan ' $z$ ' yang diterima. Karakter selain huruf dihilangkan dan dianggap sebagai delimiter.

Tabel 4. Hasil CashFolding

\begin{tabular}{ll}
\hline Input Data Uji & Output Tahapan Case Folding \\
\hline Laser Scanner yg ada di & laser scanner yg ada di printer tidak \\
$\begin{array}{l}\text { PRINTER tidak menyala, } \\
\text { roda gear mengering dan } \\
\text { fius koslet }\end{array}$ & menyala roda gear mengering dan fius \\
& \\
\hline
\end{tabular}

2. Tokenizing

Tokenizing merupakan proses pemotongan string input berdasarkan tiap kata yang menyusunya serta membedakan karakter-karakter tertentu yang dapat diperlakukan sebagai pemisah kata atau bukan. Tahapan ini dilakukan setelah inputan data uji melewati tahap Case Folding.

Tabel 5. Hasil Tokenizing

\begin{tabular}{ll}
\hline Input Data Latih hasil Case Folding & Output Tahapan Tokenizing \\
\hline Laser Scanner yg ada di PRINTER tidak & laser \\
menyala, roda gear mengering dan fius & scanner \\
koslet & yg \\
& ada \\
& di \\
& printer \\
& tidak \\
& optimal \\
& roda \\
& gear \\
& mengering \\
& dan \\
& fius \\
& koslet \\
\end{tabular}

3. Filtering

Tahap filtering adalah tahap mengambil kata - kata penting dari hasil tokenizing. Proses filtering dapat menggunakan algoritma stoplist (membuang kata yang kurang penting) atau wordlist (menyimpan kata penting). 
Tabel 6. Hasil Filtering

\begin{tabular}{ll}
\hline Input Data Latih hasil Tokenizing & Output Tahapan Filtering \\
\hline Laser & laser \\
scanner & scanner \\
yg & yg \\
ada & printer \\
di & tidak \\
printer & optimal \\
tidak & roda \\
optimal & gear \\
roda & mengering \\
gear & fius \\
mengering & koslet \\
dan & \\
fius & \\
koslet & \\
\end{tabular}

4. Stemming

Pada pencarian diagnosis terdapat satu kata yang tidak baku yaitu mengering. Maka kata tersebut harus diubah ke dalam bentuk kata yang baku melalui proses stemming yang menggunakan kamus yang berisi daftar kata-kata dari kata dasarnya begitu juga untuk singkatan-singkatan dari kata dasar.

Tabel 7. Hasil Stemming

\begin{tabular}{ll}
\hline Input Data Latih hasil Tokenizing & Output Tahapan Stemming \\
\hline Laser & laser \\
scanner & scanner \\
yg & yg \\
ada & printer \\
di & tidak \\
printer & optimal \\
tidak & roda \\
optimal & gear \\
roda & kering \\
gear & fius \\
mengering & koslet \\
dan & \\
fius & \\
koslet & \\
& \\
\hline
\end{tabular}

Selanjutnya melakukan perhitungan Certainty Factor (CF). Tabel 8 adalah contoh gejala yang terpilih yang akan digunakan dalam perhitungan. 
Tabel 8. Contoh Gejala Terpilih

\begin{aligned} & \hline \multicolumn{1}{l}{ No } Diagnosis Kerusakan Printer \\ & \hline G02 Ruang gerak laser scanner tidak optimal \\ & G03 Roda gear haus (kering) \\ & G04 Kaca scanner retak akibatnya hasil kurang optimal \\ & G05 Lampu laser scanner tidak terang \\ & G08 Kemungkinan fius F1 dan F2 pada mainboard terputus/koslet \\ & G23 Driver printer corrupt \\ & \hline\end{aligned}

Menentukan nilai CF combine, untuk mencari nilai CF combine yang digunakan untuk kaidah certainty factor apabila terdapat lebih dari satu gejala, dengan rumus :

CF Combine $=$ CFold + CFgejala $*(1-$ CFold $)$

Perhitungan dari CF combine adalah :

1. CFcombine $1=$ CFgejala $1+$ CFgejala $2 *\left(1-\mathrm{CF}_{\text {gejala } 1}\right)$

$\mathrm{CF}_{\text {old } 1}=0,18+0,17 *(1-0,18)$

2. CFcombine $\quad \begin{aligned} & =0,31 \\ & \text { CFold } 1+\text { CFgejala3 } *(1-\text { CFold } 1)\end{aligned}$

$\mathrm{CF}_{\text {old } 2}=0,39+0,03 *(1-0,39)$

$=0,40$

3. $\mathrm{CF}$ combine $3=\mathrm{CF}$ old $2+\mathrm{CFgejala} 4 *\left(1-\mathrm{CF}_{\text {old } 2}\right)$

Dari perhitungan bahwa memiliki hasil Scanner Error dengan nilai kepercayaan 0,57 yaitu mungkin. Setelah di cek pada sistem memiliki hasil yang sama dan konsisten seperti berikut :

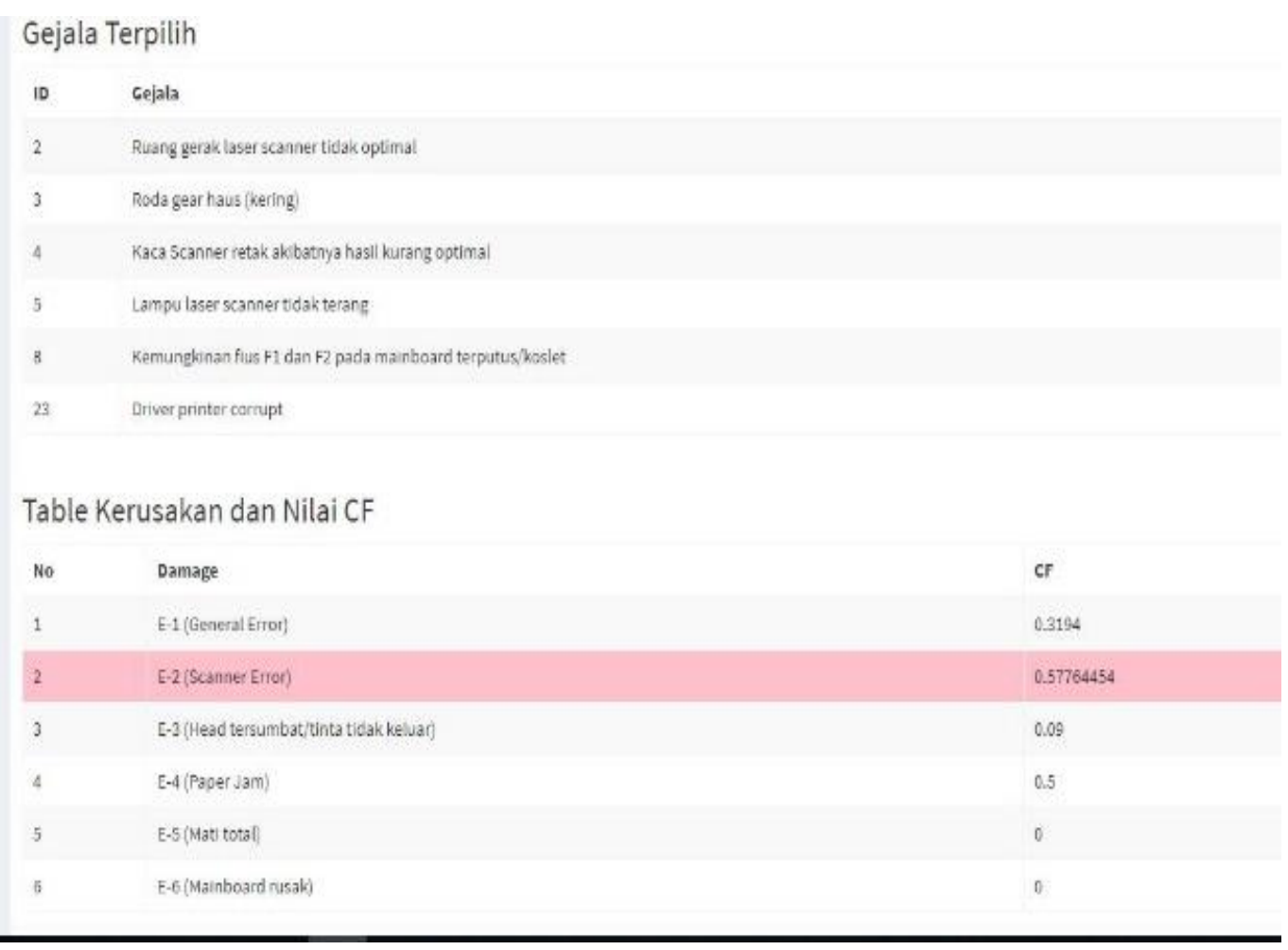

Gambar 3. Hasil CF 
Tabel 9. Interpretasi

\begin{tabular}{llc}
\hline No & Certainty Term & CF $_{\text {akhir }}$ \\
\hline 1 & Pasti Tidak & $-1,0$ \\
2 & Hampir Pasti Tidak & $-0,8$ \\
3 & Kemungkinan Besar Tidak & $-0,6$ \\
4 & Mungkin Tidak & $-0,4$ \\
5 & Tidak Tahu/Tidak Yakin & $-0,2---0,2$ \\
6 & Mungkin & 0,4 \\
7 & Kemungkinan Besar & 0,6 \\
8 & Hampir Pasti & 0,8 \\
9 & Pasti & 1,0 \\
\hline
\end{tabular}

\subsection{Tahap Impementasi}

Pada Tahap ini dilakukan pengkodean terhadap rancangan sistem yang telah dibuat, dan rancangan tampilan yang telah dibuat. Bahasa pemrograman yang digunakan adalah PHP. Untuk basis data, menggunakan MySQL. Aplikasi yang digunakan dalam membuat sistem adalah sublime text dengan framework laravel. Pada tahap untuk pengujian sistem menggunakan metode blackbox testing dan uji akurasi.

\section{a. Uji Blackbox}

Blackbox testing berfokuskan pada keperluan fungsional dari software. Karena itu pengujian blackbox memungkinkan pengembang software untuk membuat himpunan kondisi input yang akan melatih seluruh syarat-syarat fungsional suatu program.

b. Uji Akurasi Sistem

Pengujian aplikasi dilakukan untuk mengetahui seberapa akurat aplikasi yang dibuat. Pengujian dilakukan dengan membandingkan hasil diagnosis kerusakan printer oleh EPSON AUTHORIZED SERVICE CENTER dengan hasil diagnosis oleh sistem yang dibuat dan kemudian akan dihitung persentase nilai keakuratan aplikasi. Akurasi dihitung dari jumlah yang benar dengan jumlah data [13].

Akurasi $(\%)=\frac{\sum \text { data uji benar }}{\sum \text { total data } u j p} * 100 \%$

Pada penelitian ini dilakukan 12 kali uji akurasi di Epson, yaitu 2 kali setiap penyakit, dan menghasilkan akurasi :

Akurasi $(\%)=(7 / 12) \times 100 \%$

Jadi tingkat akurasi teks diagnosis terhadap akurasi uji checkbox yaitu 58,33\%.

\subsection{Pembahasan}

Pada penelitian ini telah dilakukan kombinasi proses Text Mining dan Certainty Factor dalam mendiagnosis kerusakan printer dari gejala-gejala yang terlihat. Sesuai dengan metode pengembangan RAD, yang pada tahap pertama melakukan analisa kebutuhan masalah, mendefinisikan masalah, dan tujuan informasi, kedua, melakukan perancangan sistem. Kemudian terakhir melakukan implementasi sistem.

Dari hasil wawancara dengan pakar, didapatkan informasi mengenai kerusakan dan gejala-gejala yang tergolong dalam kerusakan printer. Kerusakan tersebut antara lain adalah General Error, Scanner Erorr, Head Tersumbat/ Tinta tidak keluar, Paper Jam, Mati Total dan Mainboard Rusak dan 65\% user tidak dapat memahami perangkat-perangkat pada printer. 
Selanjutnya digunakan metode Nazief \& Adriani untuk menentukan proses pengolahan kata dalam menu pencarian gejala. Selanjutnya metode certainty factor digunakan untuk menentukan persentase nilai kepercayaan terhadap kerusakan yang telah ditentukan. Pada penelitian ini digunakan data uji sebanyak 12 buah yaitu dua uji coba pada masing-masing kerusakan. pada menu text diagnosis, ketika user menginputkan gejala kerusakan printer ternyata gejala yang dihasilkan pada sistem tidak sesuai dengan gejala yang diinginkan, sehingga memperngaruhi hasil diagnosis kerusakan printer. Ketika user menggunakan menu CheckBox hasil gejala yang dipilih sesuai dengan gejala yang dipilih oleh user.

Dari hasil uji coba yang dilakukan didapatkan akurasi antara proses kombinasi antara Text Mining dan Certainty Factor dengan hanya menggunakan algoritma Certainty Factor saja memiliki hasil 58,33\%. Karena pada menu text diagnosis, memiliki proses preprocessing sehingga kata atau kalimat yang di inputkan disesuaikan dengan database untuk mendapatkan gejala, gejala yang didapat di hitung dengan rumus algoritma Certainty Factor untuk menghasilkan diagnosis kerusakan printer.

Sedangkan pada menu CheckBox user memilih gejala sesuai dengan kerusakan yang ada pada printer. Selanjutnya gejala yang dipilih akan di hitung oleh algortima Certainty Factor untuk menghasilkan diagnosis kerusakan printer.

Dari hasil penelitian ini memiliki hasil 58,33\%, hasil ini lebih rendah jika dibandingkan dengan hasil diagnosis dari penelitian [7] yang menggunakan metode Forward Chaining dan Certainty Factor yang menghasilkan akurasi 90,91\% karena pada penelitian tersebut metode Forward Chaining dan Certainty Factor dapat memprediksi penyakit dengan tepat yang dihasilkan pada penelitian.

\section{Kesimpulan}

Berdasarkan hasil penelitian yang telah dilakukan, maka dapat disimpulkan bahwa kombinasi proses Text Mining dan certainty factor memiliki tingkat akurasi 58,33\%, karena pada menu text diagnosis, memiliki proses preprocessing sehingga kata atau kalimat yang diinputkan disesuaikan dengan database untuk mendapatkan gejala, selanjutnya gejala yang didapat di hitung dengan rumus algoritma Certainty Factor untuk menghasilkan diagnosis kerusakan printer. Sedangkan pada menu checkbox user memilih gejala sesuai dengan kerusakan yang ada pada printer. Dan gejala yang dipilih akan di hitung oleh algortima Certainty Factor untuk menghasilkan diagnosis kerusakan printer.

\section{Daftar Rujukan}

[1] Sinaga, B., Hasugian, P., and Manurung, A., 2018. Sistem Pakar Mendiagnosa Kerusakan Smarthphone Android Menggunakan Metode Certainty Factor, JIPN, Vol 3 No 1, p.56-62

[2] Agustina, I., and Haryanto, D., 2018. Sistem Pakar Dagnosis Kerusakan Pada Printer Ink Jet Dengan Menggunakan Metode Forward Chaining, JUMANTAKA, Vol 1 No 1, p. 171-180

[3] Hartono, M,. and Irsyad, E., N., M., 2016, Sistem Pakar Pendeteksi Kerusakan Printerberbasis Web Menggunakan Algoritma Forward Chaining Seminar Nasional Teknologi Informasi dan Multimedia, STMIK AMIKOM Yogyakarta, 6-7 Februari 2016, Vol 4, No 1, p.49-54

[4] Bua, Y., K., and Kungkung, A., Y., 2018, Rancang Bangun Aplikasi Sistem Pakar Mengidentifikasi Kerusakan pada Printer Menggunakan Metode Certainty Factor (Studi Kasus. CV. Dunia Komputer Jayapura), Sensitek, STMIK Pontianak, 12 Juli 2018, p.258-263

[5] Iskandar, D., 2017. Sistem Pakar Mendiagnosa Penyakit Tanaman Kol Menggunakan Metode Certainty Factor, Pelita Informatika Budi Darma, Vol 16 No 1, p.10-15

[6] Sumiati, A., Badriyah, Mada, R.D., Ariyani, 2017. Sistem Pakar Untuk Diagnosa Penyakit ParuParu Menggunakan Metode Certainty Factor Di Puskesmas Citangkil, Jurnal Protekinfo, Vol 4, p.34-42

[7] Wahyuni, I., and Kusumawati, C., 2017. Diagnosis Penyakit Infeksi Saluran Pernapasan pada Anak Menggunakan Forward Chaining dan Certainty Factor, Seminar Nasional Inovasi Teknologi, UN PGRI Kediri, 22 Februari 2017, p.427-431

[8] Cahyono, L., Ramad, L.O., Affandi, C., 2017. Sistem Pakar Diagnosis Penyakit Tanaman Buah Dalam Pot Menggunakan Metode Dempster Shafer Berbasis Web, Jurnal Teknologi Informasi, p.115-126

[9] Darmawan, R., I., Setianingrum, A., H., and Arini, 2018, Implementasi Algoritma Boyer Moore 
Pada Aplikasi Kamus Istilah Kebidanan Berbasis Web, Query, Vol 2 No 1 (April), p. 53-62

[10] Simarangkir M., 2017. Studi Perbandingan Agoritma - Algoritma Semming Untuk Dokumen Teks Bahasa Indonesia, Jurnal Inkofar, Vol 1, No 1, p. 40-46

[11] Kendall, K.E., Kendal, J.E., 2011. System Analysis and Design. Eighth Edition, Upper Saddle River, N.J: Pearson Prentice Hall.

[12] Kendall, KE. Kendall JE. 2010. Analisis dan Perancangan Sistem Informasi. Edisi 5. Diterjemahkan oleh : Thamir Abdul Hafedh. Jakarta: PT Indeks

[13] Han, J.W., Kamber, M. and Pei, J. (2012), Data Mining Concepts and Techniques. 3rd Edition, Morgan Kaufmann Publishers, Waltham. 